\title{
Destinasyon Kişiliği Boyutlarını Belirlemeye Yönelik Ampirik Bir Araştırma: Kaş Örneği
}

\author{
Aydin ÜNAL \\ Kırklareli Üniversitesi, Pınarhisar Meslek Yüksekokulu \\ aydin-unal@hotmail.com.tr \\ ORCID ID: 0000-0002-63778587
}

\begin{tabular}{lrr} 
Araştırma Makalesi & DOI: $10.31592 /$ aeusbed.663312 \\
\hline Geliş Tarihi: 23.012.2019 & Revize Tarihi: 16.07 .2020 & Kabul Tarihi:16.07.2020
\end{tabular}

\section{Atıf Bilgisi}

Ünal, A. (2020). Destinasyon kişiliği boyutlarını belirlemeye yönelik ampirik bir araştırma: Kaş örneği. Ahi Evran Üniversitesi Sosyal Bilimler Enstitüsü Dergisi, 6(2), 604-617.

\section{ÖZ}

Ulaşım, konaklama, rezervasyon, bilgi araçları ve diğer destinasyon bileşenlerinde meydana gelen gelişmeler destinasyonlar arasında rekabetin ve farklılaşma çabalarının artmasına neden olmaktadır. Bu çabaların içerisinde marka kişiliği çalışmaları önemli bir yere sahiptir. Bu çalışmada da Kaş destinasyonunda yerli turistlerin algıladıkları destinasyon kişiliği boyutlarının, genel memnuniyet düzeylerinin ve tekrar ziyaret niyetlerinin belirlenmesi amaçlanmıştır. Bu noktadan hareketle Kaş destinasyonunda tatillerini geçirmekte olan yerli turistlere toplam 220 anket formu ulaştırılmıştır. Elde edilen anket formlarından 22 tanesi anket formlarındaki cevap seçeneklerinin \%50'sinden fazlasının doldurulmamasından dolayı değerlendirme dışında bırakılmıştır. Değerlendirmeye alınan 198 anket formundan elde edilen veriler SPSS istatistiki veri analiz programı ile değerlendirilmişlerdir. Yapılan analizler neticesinde; katılımcıların çoğunluğu destinasyondan genel olarak memnun kaldıklarını (\%56) ve destinasyonu tekrar ziyaret etme niyetinde olduklarını (\%61) ifade ederken katılımcıların az bir kısmı destinasyondan genel olarak memnun kalmadıklarını (\%44) ve destinasyonu tekrar ziyaret niyetinde olmadıklarını (\%39) değerlendirilmiştir. Katılımcıların bir "insan" olarak değerlendirdiklerinde Kaş'1 "pratik, soğukkanlı, üst sınıf, modern, heyecan verici, canlı, çalışkan, neşeli, başarıl1, düzgün, güçlü, mütevazi, güvenilir, kendine güvenen, dürüst, samimi, kurumsal, sert ve dışsal" olarak algıladıkları belirlenmiştir. Ayrıca yapılan açıklayıcı (keşfedici) faktör analizi sonucunda destinasyon marka kişiliği boyutları olarak samimiyet, heyecan, yetkinlik ve seçkinlik belirlenmiştir.

Anahtar Kelimeler, Marka kişiliği, destinasyon pazarlaması, Kaş.

\section{An Empirical Research on Determining Destination Personality Dimensions: The Case of Kaş}

\begin{abstract}
Advances in transportation, accommodation, booking, information tools and other destination components increase competition and differentiation efforts among destinations. Brand personality studies play an important role within these efforts. In this study, it is aimed to determine the of revisit intention and satisfaction level, destination personality dimensions perceived by domestic tourists in Kaş destination. For this purpose, a total of 220 questionnaires were delivered to the domestic tourists who were spending their holidays in Kaş. 22 of the questionnaire forms that returned were excluded from the evaluation due to the fact that more than 50\% of the answer options were not completed. The data obtained from 198 questionnaire forms were evaluated by use of SPSS statistical data analysis program. As a result of the analyses; the majority of domestic tourists stated that they were generally satisfied with the destination $(56 \%)$ and that they intended to revisit the destination $(61 \%)$, while a small number of domestic tourists stated that they were not generally satisfied with the destination (44\%) and did not intend to revisit the destination (39\%). It was determined that the domestic tourists perceived Kaş as practical, cool, top class, modern, exciting, lively, hardworking, cheerful, successful, smooth, strong, humble, reliable, confident, honest, sincere, corporate, hard and external when they considered Kaş as a "person". In addition, as a result of exploratory factor analysis; sincerity, excitement, competence and excellence were determined as destination brand personality dimensions.
\end{abstract}

Keywords, Brand personality, destination marketing, Kaş.

\section{Giriş}

Geleneksel olarak destinasyon kavramı; sınırları kesin bir biçimde belirlenmiş bir kasabadan bir ülkeye kadar büyüklükleri değişebilen coğrafik bir alan olarak tanımlanmaktadır (Hall, 2000). Destinasyon kavramı ayrıca; "farklı doğal özellikleri ve çekicilikleri olan ve turistlerin ilgisini çeken yer" (Coltman, 1989); "turistlerin ve yerel halkın bir araya geldiği coğrafi alan (Frisk, 1989); çeşitli turistik değerlere ve özelliklere sahip ve turistlerin seyahatleri süresince ihtiyaç duyabilecekleri turistik 
ürünlerin tamamının veya bir kısmının sunulabildiği coğrafi bir mekân" (Atay, 2003) olarak da tanımlanmaktadır. Coğrafik ve fiziki sınır temelli bu tanımlar günümüzün mevcut turizm anlayışını, hizmet üretim ve sunum süreçlerini, turistlerin beklentilerini ve değerlendirmelerini açıklamakta yetersiz kalmaktadır. Destinasyon; turistlerin geçmiş deneyimlerine, eğitim düzeylerine, seyahat amaçlarına, kültürel geçmişlerine, seyahat motivasyonlarına ve kişisel değerlendirmelerine dayanan algısal bir kavram olarak tanımlanabilir. Örneğin, Londra şehri iş amaçlı seyahat eden Alman bir turist için destinasyon olarak değerlendirilirken; altı Avrupa ülkesini kapsayan ve iki hafta sürecek bir kruvaziyer turuna boş zaman değerlendirmek amacıyla katılan Japon bir turist için her bir Avrupa ülkesi veya geminin uğradığı her bir liman destinasyon olarak algılanıp değerlendirilebilmektedir (Buhalis, 2000, s. 97).

Destinasyonlar; destinasyonun kendi çevresi (sosyal, politik, yasal, teknolojik, ekonomik, kültürel ve doğal çevre unsurlarının bütünü), destinasyonun hizmet altyapısı (ulaşım, konaklama, yeme içme, alışveriş, eğlence, seyahat ve rekreasyon faaliyetlerinin ve çekiciliklerinin bütünü) ve destinasyondaki turistlerin deneyimleri ile algıları katmanlarının bileşiminden oluşan turistik ürünlerdir (Murphy, Pritchard ve Smith, 2000, s. 46). Çok bileşenli, algılara dayalı ve kişisel değerlendirmelere fazlaca maruz kalan destinasyonlarda, turistlerin beklentilerinin, deneyimlerinin, algilarının, değerlendirmelerinin, hizmet kalitesinin, memnuniyetlerinin ve tekrar ziyaret niyetlerinin ölçülmesi ve yüksek düzeyde karşılanması turizm pazarlarının yoğun ve giderek artan rekabet ortamında varlıklarını sürdürmelerinde öne çıkan unsurlar haline gelmektedir. Tüm bu süreçlerin yanı sıra destinasyonların sıradanlıktan kaçınma, benzerlerinden farklılaşma ve turistlerin algılarını bu yönde dönüştürme çabaları da önem arz etmektedir (Morgan ve Pritchard, 2002; Ritchie ve Ritchie, 1998, s. 17). Bütün bu bilgilerin 1şığında marka kişiliği kavramı ve araştırmaları ortaya çıkmıştır (Ekinci ve Hosany, 2006, s. 127).

Marka kişiliği kavramı, Amerikalı araştırmacı Aaker (1997) tarafından "bir marka ile ilişkilendirilen ve insanlara özgü özelliklerin toplamı" şeklinde tanımlanmıştır. Daha sonra bu kavram Ekinci ve Hosany (2006) tarafından destinasyon kavramı ile bütünleştirilerek "yerel halktan ziyade turist bakış açısıyla insanlara özgü birtakım kişilik özelliklerinin destinasyonlarla ilişkilendirilmesi” şeklinde destinasyon marka kişiliği kavramını tanımlamışlardır. Blain, Levy ve Ritchie (2005) destinasyon marka kişiliğini; destinasyonların benzersizliklerini vurgulamak ve farklılık yaratmak için benimsedikleri bir strateji olarak tanımlamıştır. Destinasyon marka kişiliği çalışmalarında üç temel amaca odaklanılmaktadır. Bu amaçlardan ilki; destinasyonun diğer benzerlerinden farkını ortaya koyacak isim, slogan, logo, grafik, sembol, kavram, vb. yaratmaktır. İkinci amaç ise turistlerin destinasyonla ilgili eşsiz/benzersiz deneyimini hissetmelerini ve deneyimlemelerini sağlamaktır. Son amaç ise turistlerin destinasyonla ilgili algıladıkları riskleri, bilgi arama çabalarını ve katlandıkları diğer maliyetleri minimize ederek turistlerle duygusal iletişimin sağlanmasıdır (Blain vd., 2005; Ekinci, Sırakaya Türk ve Baloğlu, 2007).

Destinasyon marka kişiliği çalışmalarının özünde insanlara özgü çeşitli kişilik özelliklerinin destinasyonlara uyarlanması yer almaktadır. Bu alanda yapılmış çalışmaların çoğunluğunun samimiyet, heyecan, yetkinlik, seçkinlik ve sertlik boyutlarında konuyu ele aldıkları görülmektedir (Aaker, 1997, s. 351; Murphy, Moscardo ve Beckendorff, 2007; Usaklı ve Baloğlu, 2011). Destinasyonlar ile marka kişiliği boyutları ilişkilendirildiğinde; Paris ve romantizm, Arjantin ve cesur, İspanya ve aile odaklı, İstanbul ve kültür örneklerinde olduğu gibi destinasyonların farklılaştırılması ve turistler açısından çekiciliklerinin arttırılması sağlanmaktadır (Sop, Kılıç ve Kurnaz Akyurt, 2012, s. 1127). Destinasyon marka kişiliği çalışmaları destinasyonlara kimlik kazandırılması (Ekinci ve Hosany, 2006; Murphy vd., 2007), turistlerin zihinlerinde canlandırılabildikleri ve samimiyet-heyecan-sertlik gibi duygular uyandıran özelliklerin oluşturulması (Ritchie ve Ritchie, 1998; Ye, 2012), turistlerin destinasyonla ilgili olumlu tavsiyelerinin ve destinasyonu tekrar ziyaret niyetlerinin arttırılmasinda (Ekinci ve Hosany, 2006; Murphy vd., 2007; Kim ve Lehto, 2013; Umur ve Eren, 2016; Ülkü, Solmaz ve Barakaz1, 2017), destinasyonların pazarlama faaliyetlerinde farklılığın ve ayırt ediciliğin vurgulanmasında (Apostolopoulou ve Papadimitriou, 2015; Rojas-Mendez, Murphy ve Papadopoulos, 2013; Usaklı ve Baloglu, 2011), destinasyonların somut ve soyut olarak betimlemelerinin kolaylaştırılmasına (Lim, 2013) olumlu katkılar sağlamaktadırlar. Bu nedenle rekabetin yoğun yaşandığı turizm sektörünün en önemli bileşeni olan destinasyonların marka kişiliği çalışmalarını etkin bir biçimde yürütmeleri 
gerekmektedir. Bu çalışmada Türkiye'den ve son yıllarda dünyanın birçok farklı ülkesinden başta dalış turizmi olmak üzere daha birçok turizm türüne katılmak üzere yerli ve yabancı turistlerin tercih ettikleri Kaş destinasyonunda, yerli turistlerin algıladıkları marka kişiliği boyutlarının belirlenmesi amaçlanmaktadır. Yapılan bu çalışmanın ilgili literatüre ve sonraki çalışmalara katkı sağlayacağı düşünülmektedir. Ancak çalışma maddi kaynaklar, zaman sınırlığı ve araştırma alanında yaşanan mevsimsel dezavantajlardan dolayı daha geniş bir örneklem büyüklüğüne uygulanamamıştır. Bu sebeple gelecekteki çalışmalarda araştırmaya dâhil edilecek turist sayısının arttırılması ve milletleri açısından farklı turistlerinde örnekleme dâhil edilmesi araştırma sonuçlarının genellenmesi ve karşılaştırılması açısından olumlu katkı sağlayacaktır.

Aaker'in (1997) 1200 katılımcı ile Amerika'da yürüttüğü çalışma sonucunda insanlara özgü kişilik özelliklerini esas alan 42 önerme (aile odaklı, canlı, erkeksi, kadınsı, sakin, genç, vb.) ve beş boyuttan (samimiyet, heyecan, yetkinlik, seçkinlik ve sertlik) oluşan bir ölçek geliştirmiştir. İlgili ölçek marka kişiliği çalışmalarında en sık kullanılan ve ilgili literatüre temel oluşturan bir kaynak olarak kabul edilmektedir.

Ekinci ve Hosany'nin (2006) Aaker tarafından geliştirilen ölçeği kullanarak 275 katılımcı ile Birleşik Krallık'ta ve bir Avrupa havaalanında yürüttükleri çalışmada destinasyon marka kişiliğini samimiyet, eğlence ve heyecan boyutları ile açıklamışlardır. Yazarların çalışması Aaker'in marka kişiliği ölçeğinin destinasyonlara da uyarlanileceğini göstermesi açısından önemlidir. Murphy ve diğerlerinin (2007) iki ayrı grup ve 480 katılımcı ile İspanya Granada'da yürüttükleri çalışmada ilk grubun destinasyon marka kişiliği algılarının samimiyet, heyecan ve sertlik boyutları ile ikinci grubun destinasyon marka kişiliği algılarının ise samimiyet, heyecan ve eğlence boyutları ile açıklandığını belirlemişlerdir.

Uşaklı ve Baloğlu'nun (2011) 368 katılımcı ile Las Vegas destinasyonunda yürüttükleri çalışmada destinasyon marka kişiliği boyutları olarak heyecan, seçkinlik, yetkinlik, modernlik ve samimiyet olarak belirlemişlerdir. Ye'nin (2012) 210 katılımcı ile Avustralya destinasyonunda yürüttügü çalışmada destinasyon marka kişiliği boyutlarını samimiyet, seçkinlik, heyecan ve sertlik olarak ifade etmiştir.

Sop’un (2013) 403 İngiliz katılımcı ile Bodrum destinasyonunda yürüttüğü çalışmada turistlerin destinasyon marka kişiliği algılarını dinamizm, samimiyet, yetkinlik ve seçkinlik boyutları ile açıklamıştır. Chen ve Phou'nun (2013) 428 katılımcı ile Kamboçya Angkor destinasyonunda yürüttükleri çalışmada turistlerin destinasyon marka kişiliği algılarını heyecan, samimiyet, seçkinlik, sağlamlık ve modernlik boyutları ile açıklamışlardır. Rojas-Mendez ve diğerlerinin (2013) 477 katılımcı ile Şangay ve Pekin destinasyonunda yürüttükleri çalışmada turistlerin Amerika ile ilgili destinasyon marka kişiliği algılarının bencillik, beceriklilik ve dostluk boyutlarında toplandığını belirlemişlerdir. Artuğer ve Çetinsöz'ün (2014) 395 katılımcı ile Alanya destinasyonunda yürüttükleri çalışmada turistlerin algıladıkları destinasyon marka kişiliği boyutlarını heyecan, samimiyet, yetkinlik ve sertlik olarak belirlemişlerdir. Türkeri'nin (2014) 380 katılımcı ile Erzurum Palandöken Kayak Merkezi'nde yürüttüğü çalışmada turistlerin destinasyon marka kişiliği algı boyutlarını canlılık, samimiyet, yetkinlik, modernlik ve seçkinlik olarak belirlemiştir. Gomez Aguiler, Yagüe ve Villasenor'un (2014) İspanya Granda ve Torremolinos destinasyonunda Birleşik Krallık'tan katılımcılarla yürüttükleri çalışmada turistlerin destinasyon marka kişiliği algılarının heyecan, sertlik, samimiyet, yetkinlik ve seçkinlik boyutlarında toplandığını belirlemiş̧lerdir.

Apostolopoulou ve Papadimitriou'nun (2015) 568 kat1lımc1 ile Yunanistan'ın Patras destinasyonunda yürüttükleri çalışmada turistlerin destinasyon marka kişiliği algılarını heyecan, seçkinlik, güzellik, yetkinlik, olumsuz kişilik ve çeşitlilik boyutları ile açıklamışlardır. Türkmen ve Köroğlu'nun (2017) 708 katılımcı ile İstanbul destinasyonunda yürüttükleri çalışmada marka kişiliği açısından Türkiye ve Yunanistan destinasyonlarını karşılaştırmışlardır ve yerli turistlerin algıladıkları destinasyon marka kişiliği boyutları olarak sertlik, samimiyet, yetkinlik-seçkinliği belirlemişlerdir. 
Motor Atasoy'un (2019) 400 katılımcı ile Cumalıkızık destinasyonunda yürüttüğü çalışmada turistlerin destinasyon marka kişiliği algılarını heyecan, samimiyet, yetkinlik ve seçkinlik boyutları ile açıklamıştır. Kırtıl'ın (2019) 2018 yılı Mayıs-Eylül döneminde Antalya il merkezini ziyaret eden 452 katılımcı yürüttüğü çalışmada turistlerin destinasyon marka kişiliği algılarını misafirperverlik, heyecan, duygusal ve geleneksel boyutları ile açıklamıştır. Çelik, Öztürk ve Çoşkun'un (2019) 2017 yılı NisanTemmuz döneminde 327 katılımcı ile İspanya'nın Endülüs destinasyonunda yürüttükleri çalışmada turistlerin destinasyon marka kişiliği algılarının heyecan, samimiyet ve eğlence boyutlarında toplandığını belirlemişlerdir. Konu kapsamında yapılan önceki çalışmalar incelendiğinde yazarların konuyu genellikle samimiyet, heyecan, yetkinlik, seçkinlik ve sertlik boyutlarıla değerlendirdikleri bazı çalışmalarda ise destinasyon marka kişiliği ses, his, görünüm, tat, koku, renk, eğlence, modernlik ve ses boyutlarıyla ve gece hayatı, restoran, hava, kültür, suç, tarih, vb. özellikleri ile değerlendirdikleri belirlenmiştir.

\section{Yöntem}

\section{Araştırma Alanının Seçim Süreci}

İlgili destinasyonun araştırma alanı olarak seçilmesinde; ulusal ve uluslararası ölçekte doğal miraslarının (Kaputaş ve Plajı, Akçagerme Plajı, Büyükçakıl Plajı, Patara ve Xhantos Antik Kenti, vb.) yanı sıra önemli dalış merkezlerinden biri olarak kabul edilmesi, sahip olduğu yerel kültürü, macera turizmi, ekoturizm, av turizmi ve kültür turizmi başta olmak üzere daha birçok turizm çeşitliliğine ve rekreasyon faaliyetlerine olanak sağlaması, destinasyonun bakirliğini koruması, Antalya $(185 \mathrm{~km}) \mathrm{ve}$ Muğla $(225 \mathrm{~km})$ gibi turizm açısından marka destinasyonlara olan yakınlığı ve her geçen yıl ulusal ve uluslararası ölçekte tanınırlığının artması (Uluslararası Kaş-Meis Yüzme Yarışması, Kaş Caz Festivali, vb.) etkili olmuştur (Kaş Kaymakamlığ

\section{Araştırmanın Veri Toplama Aracı}

Araştırmanın amacını ve kapsamını oluşturan destinasyonlarda turistlerin marka kişiliği boyutlarını belirlemeye ve ölçmeye yönelik çalışmalar ilgili literatürde mevcuttur (Aaker, 1997; Apostolopoulou ve Papadimitriou, 2015; Artuğer ve Çetinsöz, 2014; Chen ve Phou, 2013; Çelik vd., 2019; Gomez Aguiler vd., 2014; Ekinci ve Hosany, 2006; Kirt1l, 2019; Motor Atasoy 2019; Murphy vd., 2007; Sop, 2013; Özer Uca, 2015; Türkeri, 2014; Türkmen ve Köroğlu, 2017; Usaklı ve Baloğlu, 2011; Ye, 2012;). Araştırma anketinin ve önermelerinin oluşturulmasında da ilgili çalışmalardan Aaker (1997) yararlanılmıştır. İki bölümden oluşan araştırma anket formunun ilk bölümü sekiz demografik sorudan ve bu sorulara yönelik cevaplandırıcının seçebileceği ifadelerden; anket formunun ikinci bölümü ise araştırma boyutlarına ilişkin 5'li likert tipi toplam 42 ifadeden oluşmaktadır. Katılımcıların cinsiyetleri, medeni durumları, yaş aralıkları, öğrenim düzeyleri, destinasyonu ziyaret sayıları, tatillerini birlikte geçirdikleri kişi veya kişiler, tatilleri ile ilgili genel memnuniyet düzeyleri ve destinasyonu tekrar ziyaret niyetleri araştırma anketinin demografik değişkenlerini oluşturmaktadır. Destinasyon marka kişiliği değişkenleri olarak ise insanlara özgü; pratik, aile odaklı, mütevazı, dürüst, samimi, gerçek, sağl1kl1, özgün, neşeli, duygusal, arkadaş canlıs1, cesur, modaya uygun, heyecan verici, canl, soğukkanlı, genç, yaratıcı, eşsiz, güncel, bağımsız, modern, güvenilir, çalışkan, emin, akıllı, bilimsel, kurumsal, başarılı, lider, kendine güvenen, üst sınıf, göz alıcı, iyi görünümlü, sevimli, kadınsı, erkeksi, düzgün, dışsal, batıl1, güçlü ve sert özellikler çerçevesinde oluşturulmuştur.

\section{Araştırmanın Evreni ve Örneklemi}

Araştırmanın veri toplama sürecinde (Ağustos-Ekim 2019) ilgili destinasyona tam olarak kaç ziyaretçinin geldiği resmi kaynaklardan tespit edilememiştir. Bu nedenle cevaplayıcıların yönettiği toplam 220 anket formu destinasyondaki yerli turistlere yüz yüze iletişim sağlanarak uygulanmıştır. Anket uygulanan katılımcıların belirlenmesinde zaman ve maliyet avantajı, erişim kolaylığı ve eldeki mevcut veya gönüllü bireylere uygulanması avantajları nedeniyle olasılığa dayalı olmayan örnekleme yöntemlerinden kolayda örnekleme tekniğinden yararlanılmıştır (Erkuş, 2011, s. 106). Geri dönüş sağlanan anket formlarından 22 tanesi cevap kodlamalarının \%50'sinden fazlasının boş bırakılmasından 
dolayı değerlendirme dışında bırakılarak araştırmanın değerlendirme kısmına 198 anket dâhil edilmiştir ve anketlerin geri dönüş oran $1 \% 90$ olarak gerçekleşmiştir.

\section{Araștırma Verilerinin Analizi}

Araştırma sonucunda anket formlarından elde edilen veriler SPSS istatistikî veri programında analize tabi tutulmuştur. Araştırma anketinden elde edilen katılımcılara ait demografik veriler veriler yüzde ve frekans değerleriyle analiz edilmiştir. Ölçekteki likert tipi değişkenlerin güvenirliği Cronbach's Alpha katsayısından yararlanılarak analiz edilmiştir. Anketin güvenirliğini test etmek amaciyla yapılan güvenirlik analizinin Alpha değeri ,842 olarak belirlenmiştir. Elde edilen değer araştırma ölçeğinin güvenilir olduğuna işaret etmektedir (Durmuş, Yurtkoru ve Çinko, 2010, s. 89). Ölçekle ilgili diğer testlere geçilmeden önce ölçeğin normallik testi yapılmıştır. Bu çalışmada ölçeğe uygulanan normallik testi sonuçlarına göre Skewness değeri -,221 ile ,348 arasında ve Kurtosis değeri ise ,248 ile -,201 arasında değişmektedir. İlgili Skewness ve Kurtosis değerleri -1.5 ile +1.5 aralığında oldukları için ölçeğin normal dağılıma sahip olduğunu söylemek mümkündür (Tabachnick ve Fidell, 2013). Bu sonuç ölçeğin parametrik testler ( $\mathrm{t}$ test, ANOVA, vb.) için uygun olduğunu göstermektedir. Güvenirlik ve normallik analizlerinden sonra katılımcıların algıladıkları "Destinasyon Marka Kişiliği Boyutlarını" değerlendirmelerine ilişkin ölçeğin yapı geçerliğini test etmek amacıyla açıklayıcı (keşfedici) faktör analizi yapılmıştır.

\section{Bulgular}

Araştırma katılımcılarının demografik özelliklerine ilişkin genel bir değerlendirmenin yapılabilmesi için uygulanan frekans analizi (Tablo 1) sonuçlarına göre; katılımcıların \%49'u kadın ve \%51'i erkek; \%48'i bekâr ve \%52'si evli; \%10,1'i 15-24 yaş aralığında, \%52'si 25-60 yaş aralığında ve $\% 37,9$ 'u 61 yaş ve üzeri kişilerden oluşmaktadırlar. Katılımcıların \%4,5'i ilköğretim, \%20,7'si lise, $\% 19,7$ 'si önlisans, \%38,4'ü lisans ve \%16,7'si lisansüstü düzeyde öğrenime sahiptirler. Katılımcıların $\% 56,1$ 'i ilk kez ve \%43,9'u ikinci kez destinasyonu ziyaret etmişlerdir. Katılımcıların \%6,6'sı yalnız olarak, \%23,7'si eşiyle, \%25,8'i eşi ve çocuklarıyla, \%14,6's1 ailesiyle (ebeveyn), \%14,1'i kız/erkek arkadaşıyla ve \%15,2'si arkadaş grubuyla destinasyonu ziyaret etmişlerdir. Katılımcıların \%55,6's1 destinasyondan genel olarak memnun kaldıklarını, \%44,4'ü destinasyondan genel olarak memnun kalmadıklarını, \%61,1'i destinasyonu tekrar ziyaret niyetinde olduklarını ve \%38,9'u destinasyonu tekrar ziyaret etme niyetinde olmadıklarını ifade etmişlerdir.

Tablo 1

Katılımcıların Demografik Özelliklerine İlişkin Frekans Analizi Sonuçları

\begin{tabular}{|c|c|c|c|}
\hline Demografik Özellikler & & Say1 $(n)$ & Yüzde (\%) \\
\hline \multirow{2}{*}{ Cinsiyet } & Kadın & 96 & 48,5 \\
\hline & Erkek & 102 & 51,5 \\
\hline \multirow{2}{*}{ Medeni Durum } & Bekâr & 95 & 48,0 \\
\hline & Evli & 105 & 52,0 \\
\hline \multirow{3}{*}{ Yaş } & 15-24 Yaş Aralığ1 & 20 & 10,1 \\
\hline & 25-60 Yaş Aralığı & 103 & 52,0 \\
\hline & 61 Yaş ve Üzeri & 75 & 37,9 \\
\hline \multirow{5}{*}{ Öğrenim Düzeyi } & İlköğretim & 9 & 4,5 \\
\hline & Lise & 41 & 20,7 \\
\hline & Önlisans & 39 & 19,7 \\
\hline & Lisans & 76 & 38,4 \\
\hline & Lisansüstü & 33 & 16,7 \\
\hline \multirow{2}{*}{ Destinasyonu Ziyaret Sayıs1 } & İlk Ziyaretim & 111 & 56,1 \\
\hline & İkinci Ziyaretim & 87 & 43,9 \\
\hline \multirow{6}{*}{$\begin{array}{l}\text { Tatilini Birlikte Geçirdiğin } \\
\text { Kişiler }\end{array}$} & Yalnızım & 13 & 6,6 \\
\hline & Eşimle & 47 & 23,7 \\
\hline & Eşim ve Çocuklarımla & 51 & 25,8 \\
\hline & Ailemle (Ebeveynler) & 29 & 14,6 \\
\hline & Kız-Erkek Arkadaşımla & 28 & 14,1 \\
\hline & Arkadaș Grubumla & 30 & 15,2 \\
\hline
\end{tabular}




\begin{tabular}{llcc}
\hline \multirow{2}{*}{ Genel Memnuniyet Düzeyi } & Evet & 110 & 55,6 \\
& Hayır & 88 & 44,4 \\
\hline \multirow{2}{*}{ Tekrar Ziyaret Niyeti } & Evet & 121 & 61,1 \\
& Hayır & 77 & 38,9 \\
\hline Toplam & & 198 & 100 \\
\hline
\end{tabular}

Katılımcıların araştırma önermelerine ilişkin değerlendirmelerine yönelik yapılan analiz sonuçlarına göre (Tablo 2); pratik ( $\tilde{\mathrm{x}}=4,56)$, soğukkanlı $(\tilde{\mathrm{x}}=4,56)$, üst sinıf $(\tilde{\mathrm{x}}=4,56)$, modern $(\tilde{\mathrm{x}}=4,54)$, heyecan verici $(\tilde{x}=4,49)$, canlı $(\tilde{\mathrm{x}}=4,48)$, çalışkan $(\tilde{\mathrm{x}}=4,48)$, neşeli $(\tilde{\mathrm{x}}=4,47)$, başar1l $(\tilde{\mathrm{x}}=4,47)$, güçlü ( $\tilde{\mathrm{X}}=4,44)$, mütevazı $(\tilde{\mathrm{X}}=4,44)$, güvenilir $(\tilde{\mathrm{x}}=4,43)$, kendine güvenen $(\tilde{\mathrm{X}}=4,43)$, dürüst $(\tilde{\mathrm{x}}=4,43)$, samimi $(\tilde{\mathrm{X}}=4,42)$ ve kurumsal $(\tilde{\mathrm{X}}=4,41)$ önermelerini değerlendirmeleri yüksek düzeyde gerçekleşmiştir. Katılımcıların diğer önermeleri değerlendirme düzeyleri ise orta ve birbirine yakın düzeyde $(\tilde{\mathrm{x}}=4,21$ 4,39) gerçekleşmiştir.

Tablo 2

Katılımcıların Araştırma Önermelerine İlişkin Değerlendirmeleri

\begin{tabular}{|c|c|c|}
\hline Araştırma Önermeleri & Ortalama $(\tilde{\mathrm{X}})$ & Standart Sapma \\
\hline Pratik & 4,56 & ,49 \\
\hline Aile Odaklı & 4,32 & ,47 \\
\hline Mütevazı & 4,44 & ,45 \\
\hline Dürüst & 4,43 & 49 \\
\hline Samimi & 4,42 & ,49 \\
\hline Gerçek & 4,39 & ,48 \\
\hline Sağlıklı & 4,21 & 41 \\
\hline Özgün & 4,41 & 49 \\
\hline Neşeli & 4,47 &, 50 \\
\hline Duygusal & 4,34 & 47 \\
\hline Arkadaş Canlısı & 4,37 & ,48 \\
\hline Cesur & 4,36 &, 48 \\
\hline Modaya Uygun & 4,34 & ,47 \\
\hline Heyecan Verici & 4,49 &, 50 \\
\hline Canlı & 4,48 &, 50 \\
\hline Soğukkanlı & 4,56 & ,49 \\
\hline Genç & 4,24 & ,43 \\
\hline Yaratıc1 & 4,38 & 48 \\
\hline Eşsiz & 4,39 & ,48 \\
\hline Güncel & 4,33 &, 47 \\
\hline Bağımsız & 4,36 &, 48 \\
\hline Modern & 4,54 & 49 \\
\hline Güvenilir & 4,43 &, 49 \\
\hline Çalışkan & 4,48 &, 50 \\
\hline Emin & 4,39 & 48 \\
\hline Akı1ll & 4,33 & ,47 \\
\hline Bilimsel & 4,36 & 48 \\
\hline Kurumsal & 4,41 & ,49 \\
\hline Başarılı & 4,47 &, 50 \\
\hline Lider & 4,37 & ,48 \\
\hline Kendine Güvenen & 4,43 & 49 \\
\hline Üst Sinıf & 4,56 & 49 \\
\hline Göz Alıcı & 4,24 & ,43 \\
\hline İyi Görünümlü & 4,38 & ,48 \\
\hline Sevimli & 4,39 & 48 \\
\hline Kadınsı & 4,33 & ,47 \\
\hline Erkeksi & 4,22 & ,48 \\
\hline
\end{tabular}

Yapılan güvenirlik analizi sonucunda araştırmada katılımcıların "Destinasyon Marka Kişiliği”" değerlendirmelerine ilişkin ölçeğin Cronbach's Alpha katsayısı ,842 olarak bulunmuştur. Elde edilen katsayı oranları ölçeğin güvenilir olduğuna işaret etmektedir (Ural ve Kılıç, 2005, s. 258). Çalışmada 
yararlanılan açıklayıcı faktör analizi sonucunda; KMO değeri ,898 olarak ( $\mathrm{p}=0,000$ anlamlılık düzeyinde) belirlenmiştir. $\mathrm{Bu}$ değer literatürde kabul görmüş değer aralıkları çerçevesinde mükemmel olarak değerlendirilmektedir (Durmuş, vd., 2010, s. 79). Ayrıca Barlett's Test of Sphericity-Küresellik Testi sonucu 3788,410 olarak tespit edilmiştir. Bu oranın düzeyi de örneklem büyüklüğünün faktör analizi için yeterli ve uygun olduğunu göstermektedir. Açıklayıcı faktör analizinde oluşturulan matrislerin her bir elemanı her bir değişkenle her bir faktör arasındaki korelâsyonu gösteren faktör ağırlıklarıdır. Rotasyona tabi tutulmamış matrisin yorumlanması oldukça güçtür ve matrisin varimax rotasyonuna tabi tutulması gerekmektedir (İlban, 2008, s. 133). Çalışmaya dâhil edilen 198 örnekleme dikkate alındığında 0,05 anlamlılık düzeyinde bir sonuca ulaşmak için faktör yüklerini incelemek gerekmektedir. Bir değişkenin 0,3 'lük faktör yükü faktör tarafından açıklanan varyansın $\% 9$ olduğunu göstermektedir. Bu düzeydeki varyans ise önemlidir. Bir çalışmada faktör yüklerinin 0,30-0,59 olmas1 orta düzey, 0,60 ve üzerinde gerçekleşmesi yüksek düzey büyüklükler olarak değerlendirilir (Büyüköztürk, 2002, ss. 473-474). Çalışmada hem faktör yükleri açısından 0,30'un altında olan hem de eşkökenlilik (communalities) değerleri 0,50'nin altında olan önermeler değerlendirme dışı bırakılarak açıklayıcı faktör analizinin geçerliliğinin arttırılması amaçlanmıştır. Yapılan bu iki işlem sonucunda ölçekte yer alan 42 önermeden beşinin (düzgün, dışsal, batıll, güçlü ve sert) ölçekten çıkarılmasına karar verilmiştir. Kalan 37 önerme ile ikinci kez uygulanan açıklayıcı faktör analizi sonucunda bu önermelerin dört boyut altında toplandığı belirlenmiştir ve ilgili boyutların "Destinasyon Marka Kişiliği" değerlendirme ölçeği boyutları olarak; "Samimiyet", "Heyecan", "Yetkinlik" ve "Seçkinlik" şeklinde adlandırılmalarına karar verilmiştir.

Samimiyet Boyutu; pratik, aile odaklı, mütevazı, dürüst, samimi, gerçek, sağlıklı, özgün, neşeli, duygusal ve arkadaş canlısı önermelerinden oluşmaktadır. Boyut toplam varyansın 23,248'ini açıklamaktadır ve boyutun güvenirlik katsayısı ,923 olarak gerçekleşmiştir. Boyutta aile odaklı $(, 841)$ önermesi en fazla faktör yüküne sahip önerme ve duygusal $(, 678)$ en az faktör yüküne sahip önerme olmuştur. Heyecan Boyutu; cesur, modaya uygun, heyecan verici, canlı, soğukkanl, genç, yaratıcı, eşsiz, güncel, bağımsız ve modern önermelerinden oluşmaktadır. Boyut toplam varyansın 20,141'ini açıklamaktadır ve boyutun güvenirlik katsayısı ,878 olarak gerçekleşmiştir. Boyutta cesur $(, 785)$ önermesi en fazla faktör yüküne sahip önerme ve modern $(, 632)$ en az faktör yüküne sahip önerme olmuştur. Yetkinlik Boyutu; güvenilir, çalışkan, emin, akıllı, bilimsel, kurumsal, başarılı, lider ve kendine güvenen önermelerinden oluşmaktadır. Boyut toplam varyansın 17,377'sini açıklamaktadır ve boyutun güvenirlik katsayısı ,849 olarak gerçekleşmiştir. Boyutta güvenilir $(, 779)$ önermesi en fazla faktör yüküne sahip önerme ve kendine güvenen $(, 619)$ en az faktör yüküne sahip önerme olmuştur. Seçkinlik Boyutu; üst sınıf, göz alıcı, iyi görünümlü, sevimli, kadınsı ve erkeksi önermelerinden oluşmaktadır. Boyut toplam varyansın 13,211'ini açıklamaktadır ve boyutun güvenirlik katsayısı ,805 olarak gerçekleşmiştir. Boyutta üst sınıf $(, 740)$ önermesi en fazla faktör yüküne sahip önerme ve erkeksi $(, 649)$ en az faktör yüküne sahip önerme olmuştur.

Tablo 3

Araştırma Ölçeğinin Faktör Analizi Sonuçları (n=198)

\begin{tabular}{|c|c|c|c|c|}
\hline Araştırma Önermeleri & Samimiyet & Heyecan & Yetkinlik & Seçkinlik \\
\hline Aile Odaklı & ,841 & & & \\
\hline Pratik & ,818 & & & \\
\hline Mütevazı & 801 & & & \\
\hline Dürüst & 791 & & & \\
\hline Samimi & ,778 & & & \\
\hline Gerçek & ,754 & & & \\
\hline Sağliklı &, 721 & & & \\
\hline Özgün &, 714 & & & \\
\hline Neşeli & ,706 & & & \\
\hline Arkadaş Canlısı & 696 & & & \\
\hline Duygusal & 678 & & & \\
\hline Cesur & & ,785 & & \\
\hline Modaya Uygun & & ,767 & & \\
\hline Heyecan Verici & & ,741 & & \\
\hline Canlı & & 723 & & \\
\hline
\end{tabular}




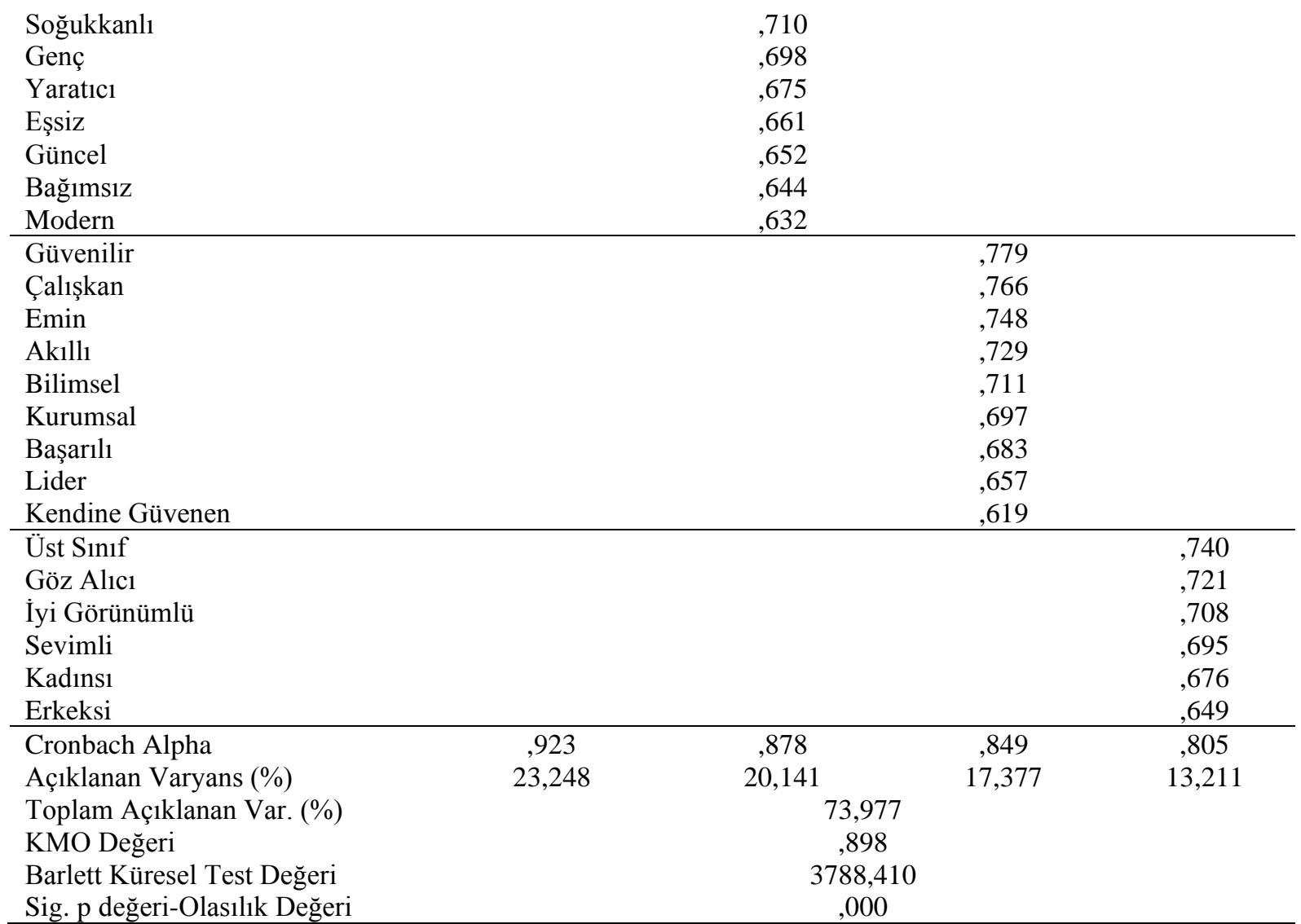

\section{Sonuç, Tartışma ve Öneriler}

Yapılan bu çalışmanın temel amacını Kaş'ı ziyaret eden katılımcıların algıladıkları destinasyon marka kişiliği boyutlarının, genel memnuniyet düzeylerinin ve tekrar ziyaret niyetlerinin belirlenmesi oluşturmaktadır. Bu amaçla yapılan analizler neticesinde; katılımcıların çoğunluğunun erkek (\%51), evli (\%52), 15-24 yaş aralığında (\%52), lise (\%21) ve lisans (\%38) düzeyinde öğrenime sahip kişilerden oluştuğu belirlenmiştir. Katılımcıların \%56'sı ilk kez destinasyona gelirken, \%24'ü eşi ve \%26'sı eşi ve çocuklarıyla destinasyonu ziyaret etmişlerdir. Katılımcıların \%56'sı destinasyondan genel olarak memnun kaldıklarını ve \%61'i destinasyonu tekrar ziyaret niyetinde olduklarını ifade etmişlerdir. Katılımcıların daha az bir kısmı (\%44) destinasyondan genel olarak memnun kalmadıklarını ve tekrar ziyaret etmek istemediklerini (\%39) belirtmişlerdir.

Katılımcıların bir "insan" olarak değerlendirdiklerinde Kaş destinasyonunu pratik ( $\widetilde{x}=4,56)$, soğukkanlı $(\tilde{X}=4,56)$, üst sinıf $(\tilde{X}=4,56)$, modern $(\tilde{X}=4,54)$, heyecan verici $(\tilde{X}=4,49)$, canlı $(\tilde{X}=4,48)$, çalışkan ( $(\tilde{x}=4,48)$, neşeli $(\tilde{X}=4,47)$, başarılı $(\tilde{X}=4,47)$, güçlü $(\tilde{x}=4,44)$, mütevazi $(\tilde{X}=4,44)$, güvenilir $(\tilde{X}=4,43)$, kendine güvenen ( $\tilde{X}=4,43)$, dürüst $(\tilde{X}=4,43)$, samimi $(\tilde{X}=4,42)$ ve kurumsal $(\tilde{X}=4,41)$ olarak algıladıkları belirlenmiştir. Araştırma boyutlarının belirlenmesi amacıyla yapılan faktör analizi sonucunda "Destinasyon Marka Kişiliği" değerlendirme ölçeği boyutları olarak Samimiyet, Heyecan, Yetkinlik ve Seçkinlik şeklinde adlandırılmalarına karar verilmiştir. İlgili boyutlar yerli ve yabancı yazınla tutarlılık göstermektedir (Aaker, 1997; Artuğer ve Çetinsöz, 2014; Çelik vd., 2019; Gomez Aguiler vd., 2014; Kırt1l, 2019; Kim ve Lehto, 2013; Motor Atasoy 2019; Özer Uca, 2015; Türkeri, 2014; Türkmen ve Köroğlu, 2017; Usaklı ve Baloglu, 2011;).

Samimiyet boyutu; pratik, aile odaklı, mütevazı, dürüst, samimi, gerçek, sağlıklı, özgün, neşeli, duygusal ve arkadaş canlısı önermelerinden oluşmaktadır. Heyecan boyutu; cesur, modaya uygun, heyecan verici, canlı, soğukkanlı, genç, yaratıcı, eşsiz, güncel, bağımsız ve modern önermelerinden oluşmaktadır. Yetkinlik boyutu; güvenilir, çalışkan, emin, akıllı, bilimsel, kurumsal, başarılı, lider ve 
kendine güvenen önermelerinden oluşmaktadır. Seçkinlik boyutu; üst sınıf, göz alıcı, iyi görünümlü, sevimli, kadınsı ve erkeksi önermelerinden oluşmaktadır.

Tablo 4

Araştırma Boyutları

\begin{tabular}{cccc}
\hline Samimiyet & Heyecan & Yetkinlik & Seçkinlik \\
\hline Aile Odaklı & Cesur & Güvenilir & Üst Sınıf \\
Pratik & Modaya Uygun & Çalışkan & Göz Alı̈ı \\
Mütevazı & Heyecan Verici & Emin & İyi Görünümlü \\
Dürüst & Canlı & Akıllı & Sevimli \\
Samimi & Soğgkkanlı & Bilimsel & Kadınsı \\
Gerçek & Genç & Kurumsal & Erkeksi \\
Sağlklıl & Yaratıc1 & Başarılı & \\
Özgün & Eşsiz & Lider & \\
Neşeli & Güncel & Kendine Güvenen & \\
Arkadaş Canlısı & Bağımsız & & \\
Duygusal & Modern & & \\
& & & \\
\hline
\end{tabular}

Yoğun rekabet ortamında varlıklarını sürdürmek isteyen destinasyon örgütleri, yönetimleri, pazarlamacıları ve işletmeleri tercih edilebilirliklerini sağlamak adına markalaşmak zorundadırlar. Markalaşma sürecinde ise destinasyon kişiliği öğelerinin ön plana çıkarılması gerekmektedir. Turistlerin ilgili öğelerle kendi kişilik özelliklerini karşılaştırması ve benzeştirmesi destinasyona olan bağlılığın ve tekrar ziyaret niyetinin oluşmasında oldukça önemlidir (Usaklı ve Baloglu, 2011; Chen ve Phou, 2013; Apostolopoulou ve Papadimitriou, 2015, s. 1134). Bu kapsamda araştırma yapılan destinasyondaki yöneticilerin ve pazarlamacıların turistler tarafından yüksek algılanan destinasyon marka kişiliği öğelerini daha da geliştirmenin yanı sıra turistlerin daha düşük düzeyde algıladıkları öğeleri de iyileştirmeleri ve geliştirmeleri gerekmektedir. Henüz destinasyonu hiç ziyaret etmemiş turistlerin destinasyona çekilmesinde ya da memnuniyetsiz turistlerin ziyaretlerinden sonra ağızdan ağıza pazarlama aracılığı ile destinasyon hakkında oluşturacakları olumsuz söylentilerin engellenmesi adına destinasyonu yoğun olarak ziyaret eden turistlerin satın alma karar süreçlerini etkileyen faktörler temelinde destinasyon kişilik ve marka çalışmalarının yürütülmesi son derece önemlidir (Türkmen ve Köroğlu, 2017). Çünkü marka kişiliği çalışmaları turistlerin çevrelerini olumlu motive etmelerinde ve tekrar ziyaret niyeti göstermelerinde destinasyonlara olumlu katkı sağlamaktadır (Ekinci vd., 2007; Usaklı ve Baloglu, 2011). Ayrıca dizilerde, sinema filmlerinde, destinasyon tanıtım çalışmalarında destinasyon marka kişiliği öğelerinin vurgulanması ilgili çalışmaların etkinliğinin arttırılmasına katkı sağlayacaktır (Motor Atasoy, 2019).

Yapılan bu çalışma maddi kaynaklar, zaman sınırlığı ve araştırma alanında yaşanan mevsimsel dezavantajlardan dolayı ulaşılabilen örneklem büyüklügü ile sınırlı kalmıştır. Bu sebeple gelecekteki çalışmalarda araştırmaya dâhil edilecek turist sayısının arttırılması ve milletleri açısından farklı turistlerinde örnekleme dâhil edilmesi araştırma sonuçlarının genellenmesi ve karşılaştırılması açısından olumlu katkı sağlayacaktır.

\section{Kaynaklar}

Aaker, J. L. (1997). Dimensions of brand personality. Journal of Marketing Research, 34(3), 347-356.

Apostopolopoulou, A. ve Papadimitriou, D. (2015). The role of destination personality in predicting tourist behavior, Implication for branding mid-sized urban destinations. Current Issues in Tourism, 18(12), 1132-1151.

Artuğer, S. ve Çetinsöz, C. B. (2014). Destinasyon imajı ile destinasyon kişiliği arasındaki ilişkiyi belirlemeye yönelik bir araştırma. İşletme Araştırmaları Dergisi, 6(1), 366-384.

Atay, L. (2003). Turistik destinasyon pazarlaması ve bir alan uygulaması. Doktora Tezi. Dokuz Eylül Üniversitesi, İzmir. 
Blain, C., Levy, S. E. ve Ritchie, B. (2005). Destination branding, insight and practices from destination management organizations. Journal of Travel Research, 43(4), 328-338.

Buhalis, D. (2000). Marketing the competitive destination of the future. Tourism Management, 21, 97116.

Büyüköztürk, Ş. (2002). Faktör analizi, temel kavramlar ve ölçek geliştirmede kullanımı. Kuram ve Uygulamada Ë̆itim Yönetimi, 32, 470-483.

Coltman. M. M. (1989). Tourism marketing. New York: Van Nostrand Reinhold.

Çelik, S., Öztürk, E. ve Çoşkun, E. (2019). Turistlerin destinasyon kişiliği ve kalite algılarının tekrar gelme eğilimleri üzerindeki etkileri: İspanya/Endülüs bölgesinde bir araştırma. Journal of Tourism and Gastronomy Studies, 7(1), 340-357.

Chen, C. F. ve Phou, S. (2013). A closer look at destination, image, personality, relationship and loyalty. Tourism Management, 36, 269-278.

Durmuş, B., Yurtkoru, S. E. ve Çinko, M. (2010). Sosyal bilimlerde SPSS'le veri analizi. Ankara: Beta Yayınc1lik.

Ekinci, Y. ve Hosany, S. (2006). Destination personality, an application of brand personality to tourism destinations. Journal of Travel Research, 45, 127-139.

Ekinci, Y., Sirakaya Türk, E. ve Baloglu, S. (2007). Host image and destination personality. Tourism Analysis, 12, 433-446.

Erkuş, A. (2011). Davranış bilimleri için bilimsel araştırma süreci (güncellenmiş üçüncü baskl). Ankara: Seçkin Yayıncılık.

Frisk, L. (1999). Seperate worlds-attitudes and value towards tourism develapment and co-operation among public organizations and private enterprises in Nothern Sweden. Conferance Proceedings of Forksarforum, 16-17 November 1999, Östersund.

Gomez Aguilar, A., Yagüe, M. J., ve Villasenor N. (2014). Destination brand personality, an application to Spanish tourism. International Journal of Tourism Research, 18(3), 210-219.

Hall, C. M. (2000). Tourism planning, policies, processes, relationships. United Kingdom: Prentice Hall.

İlban, O. M. (2008). Seyahat acenta yöneticilerinin destinasyon marka imajı algıları üzerine bir araştırma. Ege Akademik Bakış, 8(1), 121-152.

Kaş Kaymakamlığı. (2019). İlçemiz. http,//www.kas.gov.tr/ilcemiz adresinden 20.12.2019 tarihinde erişilmiştir.

Kırtıl, G. İ. (2019). Unutulmaz turizm deneyimi, destinasyon marka kişiliği, destinasyon aidiyeti, tatmin ve davranışsal niyet ilişskisi, Antalya örneği. Yüksek Lisans Tezi. Akdeniz Üniversitesi, Antalya.

Kim, S. ve Lehto, Y. X. (2013). Projected and perceived destination brand personalities, the case of South Korea. Journal of Travel Research, 52(1), 117-130.

Lim, S. (2013). The effect of destination personality and self-destination congruity on visitors' intentions. Master's Thesis. Texas A\&M University, Texas. 
Morgan, N., Pritchard, A. ve Pride, R. (Ed.) (2012). Creating the unique destination propositon. Oxford, Butterworth-Heinemann.

Motor Atasoy, D. (2019). Turizm destinasyonu marka kişiliğini belirlemeye yönelik bir araştırma: Cumalıkzzk köyü örneği. Yüksek Lisans Tezi. Sakarya Uygulamalı Bilimler Üniversitesi, Sakarya.

Murphy, P., Pritchard, P. M. ve Smith, B. (2000). The destination product and its impact on traveller perceptions. Tourism Management, 21, 43-52.

Murphy, P., Moscardo, G. ve Beckendorff, P. (2007). Using brand personality to differantiate regional tourism destinations. Journal of Travel Research, 46, 5-14.

Özer Uca, S. (2015). Şehir pazarlaması kapsamında marka kişiliği ve marka sadakati ilişkisi, Edirne ili örneği. Beykent Üniversitesi Sosyal Bilimler Dergisi, 8(2), 6-31.

Ritchie, J. R. B. ve Ritchie, J. R. R. (1998). The branding of the tourism destinations. Annual Congress of International Association of Scientific Expert in Tourism, Morocco.

Rojas-Mendez, J. I., Murphy, S. A. ve Papadopoulos, N. (2013). The US brand personality, a sino perspective. Journal of Business Research, 66(8), 1028-1034.

Sop, S. A., Kılıç, B. ve Kurnaz Akyurt, H. (2012). Destinasyon kişiliği ve memnuniyet iliş̧isi, yerli turistler üzerine bir araştırma. 13. Ulusal Turizm Kongresi, 6-9 Aralık 2012, Antalya.

Sop, S. A. (2013). Destinasyon kişiliği, benlik uyumu ve sadakat ilişkisi, Bodrum örneği. Yüksek Lisans Tezi. Muğla S1tkı Koçman Üniversitesi, Muğla.

Tabachnick, B. G. ve Fidell, L. S. (2013). Using multivariate statistics. Boston: Pearson.

Türkeri, İ. (2014). Destinasyon aidiyeti oluşturulmasında destinasyon imajının ve kişiliğinin rolü: Klş turizmi örneği (Palandöken Kayak Merkezi). Yüksek Lisans Tezi. Atatürk Üniversitesi, Erzurum.

Türkmen, S. ve Köroğlu, A. (2017). Destinasyon kişiliği araştırması: Türkiye-Yunanistan örneği. Balıkesir Üniversitesi Sosyal Bilimler Enstitüsü Dergisi, 20(37), 397-429.

Umur, M. ve Eren, D. (2016). Destinasyon imajı ve destinasyon kişiliğinin, ziyaretçi memnuniyeti ve geleceğe yönelik ziyaretçi davranışı üzerine etkisi: Kapadokya örneği. Kırıkkale Üniversitesi Sosyal Bilimler Dergisi, 6(1), 271-294.

Ural, A. ve Kılıç, İ. (2005). Bilimsel araştırma süreci ve SPSS ile veri analizi. Ankara: Detay Yayıncılık.

Usakl1, A. ve Baloglu, S. (2011). Brand personality of tourist destinations, an application of selfcongruity theory. Tourism Management, 32, 114-127.

Ülkü, A., Solmaz, A. S. ve Barakazı, M. (2017). Destinasyon kişiliğinin turistlerin davranışsal niyetleri üzerindeki etkisi, Şanlıurfa örneği. Uluslararası Sosyal Araştırmalar Dergisi, 10(53), 986-994.

Ye, S. (2012). The impact of destination personality dimensions on destination brand awareness and attractiveness, Australia as a case study. Tourism, an International Interdisciplinary Journal, 60(4), 397-409. 


\section{Extended Abstract}

\section{Introduction}

Advances in transportation, accommodation, booking, information tools and other destination components increase competition and differentiation efforts among destinations. Brand personality studies play an important role within these efforts. In this study, it is aimed to determine the revisit intention and satisfaction level, destination brand personality dimensions perceived by domestic tourists in Kaş destination. It is thought that this research will contribute to the related literature and subsequent studies. However, the research could not be applied to a larger sample size due to the limitation of financial resources, time constraints and seasonal disadvantages in the research area. For this reason, increasing the number of tourists to be included in the future researches and including the sampling of tourists different in terms of nationality will make a positive contribution to the generalization and comparison of the research results.

\section{Method}

\section{Selection of Research Area}

Kas was selected as research area due to the fact that it is recognized as one of Turkey's and the world's important natural heritage (Kaputaş and its beach, Akçagerme Beach, Büyükçakıl Beach, Patara and Xhantos ancient city, etc.) and one of the diving centers. The relevant destination has also local culture and provides sea-sand-sun tourism, diving tourism, adventure tourism, eco-tourism, hunting tourism and cultural tourism activities and many other tourism opportunities and recreation activities. The destination was selected as research area also due to the fact that it has preserved its virginity; that it is close to the brand destinations as Antalya $(185 \mathrm{~km})$ and Muğla $(225 \mathrm{~km})$ and that its national and international recognizability increases year by year (International Kaş-Meis Swimming Competition, Kaş Jazz Festival, etc.).

\section{Data Collection Tool}

Aaker's (1997) study were utilizyed in the formation of the research questionnaire and propositions. The first part of the research questionnaire consisted of 8 demographic questions and the statements that the respondents could choose for these questions; and the second part of the questionnaire consisted of 42 Likert type statements (very high, high, medium, low, very low range) related to the research dimensions.

\section{The Universe and Sample of the Research}

Any statistics regarding exactly how many domestic tourists visited the destination during the data collection process of the research (August-October 2019) could not be reached. For this reason, a total of 220 traditional questionnaires administered by the respondents were applied by providing faceto-face communication to domestic tourists in the destination. The convenience sampling method which is one of the non-probability sampling methods was used in the selection of domestic tourists to whom the questionnaire forms would be delivered. 22 of the returned questionnaires were excluded from the evaluation because more than $50 \%$ of the response codes were left blank.

\section{Analysis of Research Data}

The data obtained from the questionnaire forms were analyzed by use of SPSS statistical data program. Data on the demographic variables of the domestic tourists obtained from the survey were analyzed with percentage and frequency values. The reliability of the Likert-type variables in the scale was analyzed using the Alpha model. The normality test of the scale was performed before the other tests related to the scale were done. Within the scope of the normality test, the significance level of the Shapiro-Wilks values of the data was found to be $p>0,05$. After reliability and normality analyses, 
exploratory factor analysis was conducted to test the construct validity of the scale regarding the "Destination Brand Personality Dimensions" perceived by domestic tourists.

\section{Findings}

As a result of the analyses; it was determined that the majority of the domestic tourists were male $(51 \%)$, married (52\%), in 15-24 age group (52\%). $21 \%$ of them were high school graduate, while $38 \%$ of them had bachelor's degree. While $56 \%$ of the domestic tourists came to the destination for the first time, $24 \%$ visited the destination with their spouse and $26 \%$ with their spouse and children. $56 \%$ of the domestic tourists stated that they were generally satisfied with the destination and $61 \%$ stated that they intended to revisit the destination. Fewer of the domestic tourists (44\%) stated that they were generally not satisfied with the destination and did not want to revisit it (39\%). It was determined that the domestic tourists perceived Kaş as practical, cool, top class, modern, exciting, lively, hardworking, cheerful, successful, smooth, strong, humble, reliable, confident, honest, sincere, corporate, hard and external when they considered Kaş as a "person". As a result of the factor analysis conducted to determine the dimensions of the research, it was decided that the dimensions of the "Destination Brand Personality" assessment scale should be named Sincerity, Excitement, Competence and Excellence. The relevant dimensions are consistent with domestic and foreign literature.

\section{Discussion and Suggestions}

Destination organizations, management, marketers and businesses that want to survive in an intense competitive environment have to brand in order to ensure their preferability. In the branding process, destination personality elements should be brought into the forefront. Tourists' comparison and simulation of their personality traits with the related elements is very important in establishing the loyalty to the destination and the intention to revisit it. In this context, the managers and marketers in the destination where the research was conducted need to improve the elements of destination brand personality which were highly perceived by tourists as well as to improve and develop the elements perceived by tourists at a lower level. It is extremely important to conduct destination personality and brand studies on the basis of factors that affect the purchasing decision processes of tourists who visit the destination intensively in order to prevent the negative rumors about the destination through the word of mouth marketing after the visits of dissatisfied tourists and to attract the tourists who have not visited the destination yet. In addition, highlighting destination brand personality elements in serials, cinema films and destination promotion activities will contribute to increase the effectiveness of the related studies. 
Ekler

Destinasyon Kişiliği Boyutlarını Belirlemeye Yönelik Amprik Bir Araştırma: Kaş Örneği Demografik İfadeler

$\begin{array}{lll}\text { 1. Cinsiyetiniz? } & \text { ( ) Kadın } & \text { ( ) Erkek } \\ \text { 2. Medeni Durumunuz? } & \text { () Bekâr } & \text { ( ) Evli }\end{array}$

3. Yaşınız? () 15-24 Yaş Arası $\quad$ () 25-60 Yaş Aras

4. Eğitim Durumunuz? ( ) İlköğretim () Lise

5. Kaş'ı Kaçıncı Ziyaretiniz? () İlk Ziyaret () 2. Ziyaret

6. Kaş’ta tatilinizi kiminle ya da kimlerle geçiriyorsunuz? () Yalnız () Eşimle () Eşim ve Çocuklarımla () Ailemle (Ebeveyn) () Kız/Erkek Arkadaşımla () Arkadaş Grubumla

7. Genel olarak Kaş ziyaretimden memnun kaldım. () Evet () Hayır

8. Tekrar Kaş'a gelmeyi düşünürüm.

() Evet

() Hayır

Sayın Katılımcı; Lütfen aşağıda yer alan ifadelerle ilgili düşüncelerinizi Kaş’ı bir İNSAN olarak düşünüp (5)

Çok Yüksek (4) Yüksek (3) Orta (2) Düşük (1) Çok Düşük olacak şekilde belirtiniz.

\begin{tabular}{|c|c|c|c|c|c|}
\hline İfadeler & & De ̌̆ & rlenc & iirme & \\
\hline Pratik & (5) & $(4)$ & (3) & (2) & $(1)$ \\
\hline Aile Odaklı & (5) & (4) & (3) & $(2)$ & (1) \\
\hline Mütevazı & (5) & (4) & (3) & (2) & (1) \\
\hline Dürüst & (5) & (4) & (3) & (2) & (1) \\
\hline Samimi & $(5)$ & (4) & (3) & $(2)$ & (1) \\
\hline Gerçek & (5) & (4) & (3) & $(2)$ & $(1)$ \\
\hline Sağliklı & (5) & (4) & (3) & (2) & (1) \\
\hline Özgün & $(5)$ & (4) & (3) & $(2)$ & (1) \\
\hline Neşeli & (5) & (4) & (3) & $(2)$ & $(1)$ \\
\hline Duygusal & (5) & (4) & (3) & (2) & (1) \\
\hline Arkadaş Canlısı & $(5)$ & (4) & (3) & $(2)$ & (1) \\
\hline Cesur & (5) & (4) & (3) & $(2)$ & $(1)$ \\
\hline Modaya Uygun & (5) & (4) & (3) & (2) & (1) \\
\hline Heyecan Verici & $(5)$ & (4) & (3) & (2) & (1) \\
\hline Canl1 & (5) & (4) & (3) & $(2)$ & (1) \\
\hline Soğukkanlı & (5) & (4) & (3) & $(2)$ & (1) \\
\hline Genç & (5) & (4) & (3) & (2) & (1) \\
\hline Yaratıc1 & (5) & (4) & (3) & $(2)$ & (1) \\
\hline Eşsiz & $(5)$ & (4) & (3) & $(2)$ & $(1)$ \\
\hline Güncel & (5) & (4) & (3) & (2) & (1) \\
\hline Bağımsız & (5) & (4) & (3) & (2) & (1) \\
\hline Modern & $(5)$ & $(4)$ & (3) & $(2)$ & $(1)$ \\
\hline Güvenilir & (5) & (4) & (3) & (2) & (1) \\
\hline Çalışkan & (5) & (4) & (3) & (2) & (1) \\
\hline Emin & $(5)$ & (4) & (3) & $(2)$ & $(1)$ \\
\hline Ak1llı & (5) & (4) & (3) & (2) & (1) \\
\hline Bilimsel & (5) & (4) & (3) & (2) & (1) \\
\hline Kurumsal & $(5)$ & $(4)$ & (3) & $(2)$ & $(1)$ \\
\hline Başarıl1 & (5) & (4) & (3) & $(2)$ & (1) \\
\hline Lider & (5) & (4) & (3) & (2) & (1) \\
\hline Kendine Güvenen & $(5)$ & (4) & (3) & $(2)$ & $(1)$ \\
\hline Üst Sinıf & (5) & (4) & (3) & $(2)$ & (1) \\
\hline Göz Alıcı & (5) & (4) & (3) & (2) & (1) \\
\hline İyi Görünümlü & $(5)$ & (4) & (3) & $(2)$ & $(1)$ \\
\hline Sevimli & $(5)$ & (4) & (3) & $(2)$ & $(1)$ \\
\hline Kadınsı & (5) & (4) & (3) & (2) & (1) \\
\hline Erkeksi & (5) & (4) & (3) & $(2)$ & (1) \\
\hline Düzgün & $(5)$ & (4) & (3) & $(2)$ & $(1)$ \\
\hline Dişsal & (5) & (4) & (3) & (2) & (1) \\
\hline Batıli & (5) & (4) & (3) & (2) & (1) \\
\hline Güçlü & $(5)$ & $(4)$ & (3) & $(2)$ & $(1)$ \\
\hline Sert & (5) & (4) & (3) & (2) & (1) \\
\hline
\end{tabular}

